\title{
EFFECTS OF SHEA OIL ON THE HISTOLOGY AND ENZYMES OF THE LIVER
}

CORRESPONDANCE to MADU NOM GADZAMA Postal Address: Madu Nom Gadzama, P. O. Box 2324, Maiduguri, Borno state, Nigeria. Phone No: (+234) 8032283514. Email: gadzama47@gmail.com

\begin{abstract}
The study was carried out to investigate the effect of Shea oil on the histology and enzymes of liver of Albino Wistar rats. Twenty-five adult Albino Wistar rats weighing between $98.8 \mathrm{~g}$ to $348 \mathrm{~g}$ were randomly grouped into five groups of five rats each. Group I served as control and was given water and feed only ad libitum. Groups II, III, IV, and V were given $500 \mathrm{mg} / \mathrm{kg}, 1000 \mathrm{mg} / \mathrm{kg}, 1500 \mathrm{mg} / \mathrm{kg}$, and $1500 \mathrm{mg} / \mathrm{kg}$ of Shea oil orally for the duration of 28days. Groups I-IV were sacrificed after 28days while Group $V$ was left for additional 14 days post treatment after the rats in the group were sacrificed. Liver tissues were harvested for histopathological observations and blood samples were collected for liver function tests (Asparate aminotransferase (ASAT), Alanine aminotransferase (ALAT) and Alkaline phosphate (ALP)). Cell morphological changes seen under light microscopic level the rats in the control group have normal liver architecture while steatosis, fatty changes, inflammation, and necrosis where observed in the experimental groups. The hepatocytes were becoming irregular with narrowing sinusoid showing sign of recovery in group V. There was no significant effect on serum level of ASAT, ALP, total protein and urea while the change in ALAT and albumin level was significante $(p>0.05)$. We therefore recommended that people consuming Shea oil should do so with care. Further investigations should be carried out.
\end{abstract}

Key Words: Vitellaria Paradoxa, Enzymes and Liver.

\section{INTRODUCTION}

Shea butter is an off-white or ivory coloured fat extracted from the nut of African Shea tree (Vitellaria Paradoxa). Shea tree is a plant that is locally abundant in Nigeria Savannah zones (Aguzue et al., 2013). Varieties of plants and plant products have been used continuously by man as food, bio fuel and drugs in treatment of diseases (sheriff et al., 2001). Shea oil serves as source of edible oil for many households in many parts of the Sahel Africa, particularly Northern Nigeria (Jamala et al., 2013).

Oral administration of Shea butter extract was found to have no ulcerogenic effect in rats
(Egoldvier, 2011). Nakate, (2011) reported that Shea oil induce no clinically relevant change in blood chemistry. Israel et al., (2014) reported that consumption of Shea butterbased diet does not affect hepatic function.

This study was aimed at determining the effect of oral administration of Shea oil on the histology, enzymes and some biomarkers in albino rats, this is due to the increased utilisation of Shea oil for medicinal benefits and substitute for fat in rural communities of Borno state, Nigeria.

\section{MATERIALS AND METHODS}

Shea butter was purchased from the open market; Askira-Uba main market, Askira-Uba Local Government area, Borno State -Nigeria.
The Shea was melted, poured into a glass bottle and kept for further use. The Shea butter was always warmed into Shea oil before 
administration. Twenty-five adult rats of both sexes were used for the experiment. The rats were purchased from faculty of veterinary medicine university of Maiduguri, Borno State - Nigeria. The rats were kept in plastic cages and allowed to acclimatise to the laboratory condition for a period of two weeks before the commencement of the experiments, the experiment was approved by the department of Human Anatomy University of Maiduguri. The rats were feed growers mash and were provided with water ad Libitum. The twentyfive rats were randomly divided into five groups of five rats each. Groups II, III, and IV were treated orally with $500 \mathrm{mg} / \mathrm{kg}, 1000 \mathrm{mg} / \mathrm{kg}$ and $1500 \mathrm{mg} / \mathrm{kg}$ of Shea oil respectively for a period of 28 days. Group V were given same dose $(1500 \mathrm{mg} / \mathrm{kg})$ as group IV, while group I served as the control group and were treated with distilled water for the same period. Group V served as recovery group and were allowed for 14 days post-treatment period during which there is no administration of test substance. This is to observe for reversibility or non-reversibility and delayed occurrence of toxic effect of the Shea oil.

After twenty-eight days groups I - V were sacralised and blood was collected for liver function test using Randox Laboratory Kits procedure. The livers were harvested for routine histological procedure for light microscopic viewing. After additional fourteen days, group $\mathrm{V}$ was also sacrificed, blood collected and their livers harvested for the above-named procedure. The data obtained from the liver function test were expressed as means \pm SD. The data obtained were evaluated by analysis of variance (ANOVA) using Instat Graph pad version 3. 0, a p $<0.05$ was considered significantly at a $95 \%$ confidence interval.

\section{RESULTS}

The groups treated with $500 \mathrm{mg} / \mathrm{kg}$, $1000 \mathrm{mg} / \mathrm{kg}$ and $1500 \mathrm{mg} / \mathrm{kg}$ Shea oil showed no significant difference in serum level of liver enzymes (ASAT, ALP), albumin and total protein compared to the control group. On the other hand, only the group treated with $1500 \mathrm{mg} / \mathrm{kg}$ showed significant difference in serum level of ALAT compared to the control group $(p<005)$.

Table: 1 showing the effect of Shea oil on the liver enzymes and some biomedical

\begin{tabular}{|l|l|l|l|l|l|}
\hline & Control & $\begin{array}{l}\text { II } \\
500 \mathrm{mg} / \mathrm{kg}\end{array}$ & $\begin{array}{l}\text { III } \\
1000 \mathrm{mg} / \mathrm{kg}\end{array}$ & $\begin{array}{l}\text { IV } \\
1500 \mathrm{mg} / \mathrm{kg}\end{array}$ & $\begin{array}{l}\text { V } \\
1500 \mathrm{mg} / \mathrm{kg}\end{array}$ \\
\hline Albumin & $31.5 \pm 4.44^{*}$ & $34.2 \pm 2.78^{*}$ & $34.5 \pm 4.44^{*}$ & $28.0 \pm 3.54^{*}$ & $29.2 \pm 1.19^{*}$ \\
\hline Total protein & $74.00 \pm 5.35$ & $86.6 \pm 17.39$ & $89.75 \pm 20.78$ & $76.8 \pm 10.98$ & $73.0 \pm 14.93$ \\
\hline ALAT & $38.75 \pm 6.60^{*}$ & $40.60 \pm 7.05^{*}$ & $34.00 \pm 10.33^{*}$ & $26.4 \pm 4.34^{*}$ & $33.6 \pm 3.64^{*}$ \\
\hline ASAT & $105.75 \pm 22.46$ & $111.60 \pm 7.77$ & $118.25 \pm 7.23$ & $96.00 \pm 2.12$ & $103.4 \pm 5.41$ \\
\hline ALP & $186.0 \pm 59.08$ & $225.2 \pm 66.70$ & $197.5 \pm 64.70$ & $172.6 \pm 67.63$ & $211.2 \pm 68.47$ \\
\hline URE & $4.78 \pm 0.57$ & $5.72 \pm 0.64$ & $4.78 \pm 0.58$ & $4.64 \pm 1.01$ & $5.48 \pm 1.16$ \\
\hline CRT & $74.75 \pm 20.02$ & $71.4 \pm 4.6$ & $76.25 \pm 8.42$ & $84.67 \pm 23.86$ & $71.25 \pm 11.30$ \\
\hline
\end{tabular}

Values are expressed as mean \pm SD $p>0.05 . *=$ Significant, URE $=$ Urea, CRT $=$ Creatinine 


\section{Microscopic Anatomy of the Liver}

Microscopically, the structure of the liver appears as solid organ composed of highly packed cells termed hepatocytes. The outré surface of the liver is covered by collagenous tissue called Glisson's capsule over which is a layer of mesothelial cells from the visceral peritoneum (Young et al., 2006). The hepatocytes are secretory epithelial cells derived from foregut endoderm, the cells are one or two cells thick, they discharge bile into tiny inter cellular channels called bile canaliculi, in contrast, their so-called internal secretion (glucose, plasma proteins and lipoproteins) are released into the blood. Hence hepatocytes have some part of their surface bordering on bile canaliculi, and parts that border on wide venous blood vessels known as hepatic sinusoids, the sinusoids can just be seen as a

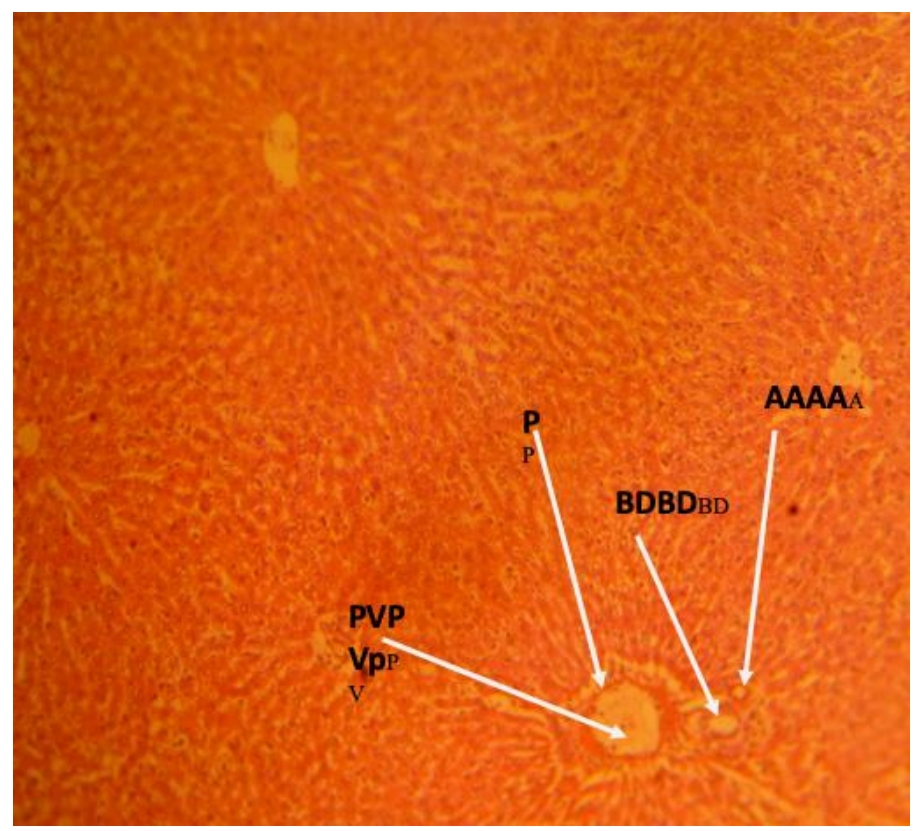

Fig.1. photomicrograph of cross section of liver of rats of control group showing sinusoid(S), portal tract(p), Bile duct $(B D)$, portal vein $(P V)$ and hepatic artery $(A) H$ and $E$ stains $\times 200$. paler stained space between the plates of the liver cell when stained with hematoxyline and eosine stains, the sinusoids form a very low resistance system of vascular channel that allows blood to come into contact with the hepatocyte over a huge surface (Young et al., 2006).

Normal liver architecture is shown in fig. 1 with normal hepatocytes, bile duct, sinusoid, portal tract, portal vein and artery, micro and macro vesicular-steatosis was observed in group administered $500 \mathrm{mg} / \mathrm{kg}$ fig.2. The liver of albino rats administered $100 \mathrm{mg} / \mathrm{kg}$ of Shea oil show areas of fatty changes and ballooned hepatocytes (fig.3), there were area of necrosis and inflammation of hepatocytes in liver of rats administered $1500 \mathrm{mk} / \mathrm{kg}$ Shea oil (fig.5).

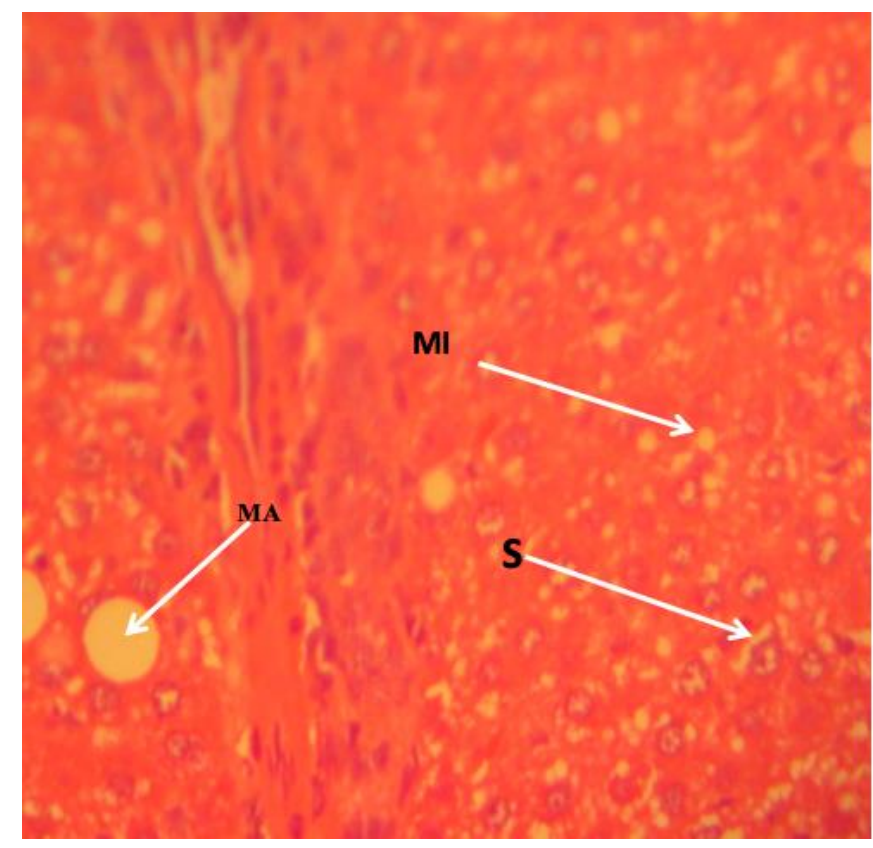

Fig. 2. Photomicrograph of the cross section of liver of rat administered $500(0.5 \mathrm{ml}) \mathrm{mg} / \mathrm{kg}$ Shea oil for duration of twenty eight days showing macrovesicular steatosis (MA), microvesicuular steatosis (MI), and sinusoid(S). $\mathrm{H}$ and $\mathrm{E}$ stain $\times 200$ 


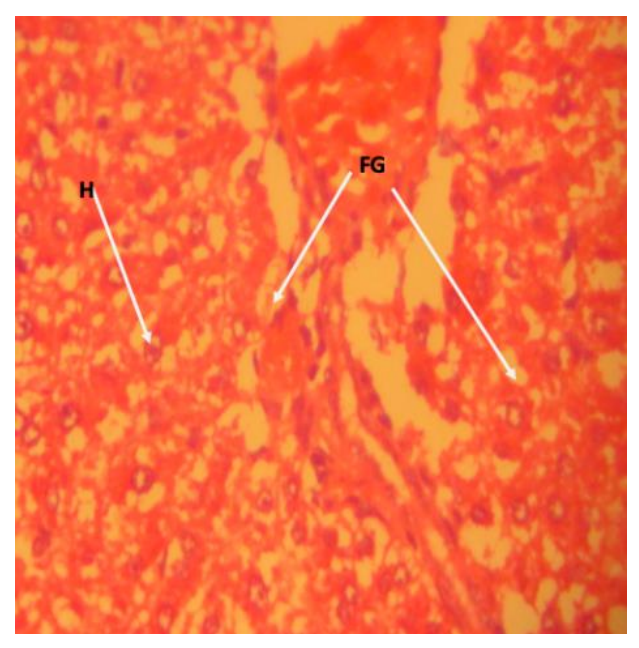

Fig.3 Photomicrograph of the cross section Fig. 4. Photomicrograph of the cross section of of liver of albino wistar rat administered the liver of an albino Wister rat administered $1000(1 \mathrm{ml}) \mathrm{mg} / \mathrm{kg} / \mathrm{day}$ of Shea oil for twenty eight days showing fatty change (FG) and hepatocyte Hand E stains x 200

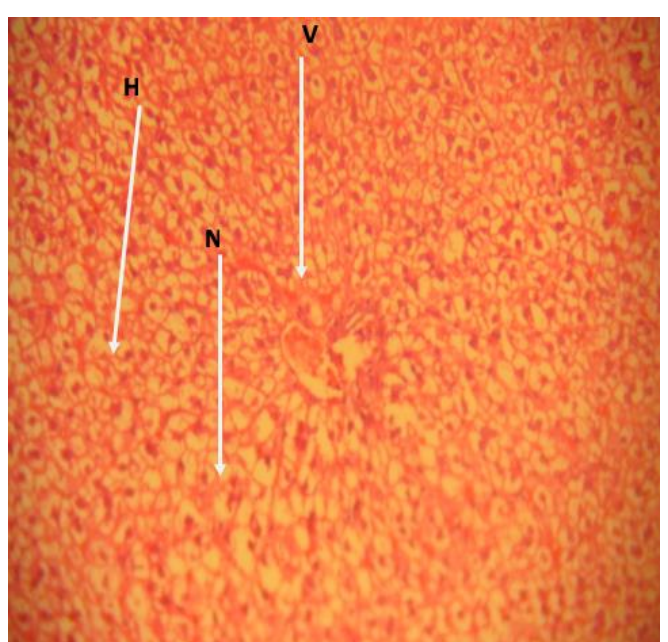

$1500(1.5 \mathrm{ml}) \mathrm{mg} / \mathrm{kg}$ of Shea oil for twenty eight showing hepatocyte $(H)$, focal area of necrosis $(\mathrm{N})$ and venule $(\mathrm{V}) . \mathrm{H}$ and $\mathrm{E}$ stains $\times 200$

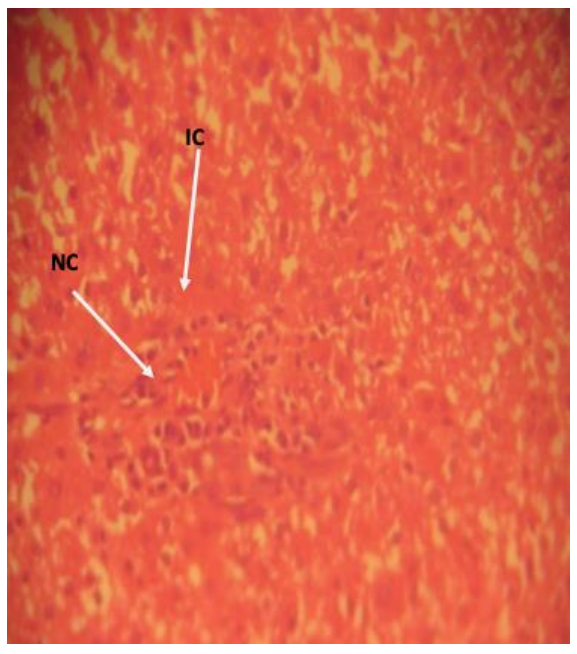

Fig.5: Photomicrograph of cross section of the liver. Of albino wistar rat administered $1500(\mathrm{ml}) \mathrm{mg} / \mathrm{kg} /$ day of shear oil for twenty eight days. Post administration showing areas of necrosis (NC) and inflammatory cells (IC) $\mathrm{H}$ and $\mathrm{E}$ stains.

\section{DISCUSSION}

The oil from Shea nut is used continuously for cooking in various communities in Nigeria, the oil is also used in traditional and modern medical practice because of its abundance and medicinal properties (Eyitayo, 2007).

At light microscopic level Shea oil induced micro and macro vesicular-steatosis in the liver of Wister albino rats, Tiniakos et al (2010) reported that the administration of western diet to mice will cause steatosis, Reyes syndrome, tetracycline, alcohol consumption, diabetics, obesity and corticosteroids have also been reported to be associated to steatosis (Goldam, 2003). Fatty changes, obstruction of liver sinusoid and necrosis were also observed which further suggest that Shea oil may be toxic to liver, necrosis of the liver cells were observed by Boyd and Bereczky (1965) in rats administered $500 \mathrm{mk} / \mathrm{kg}$ of paracetamol, Emily et al (2018) reported that fatty liver may lead to fat inflammation and hepatic necrosis.

There was no significant change in the serum levels of ASAT, ALP, Total Protein, creatinine and urea, similar result were observed in study to determine the effect of Shea oil on some biomedical parameters in rats (Akinwale et al., 2012). As against the study Wanyam et al (2012), it was observed that there is a significant effect by Shea oil on the serum level of ALAT and Albumin, Nehu (2007) reported that ALAT is specific indicator for liver damage which may be due to fatty changes, necrosis and steatosis observed at the light microscopic level. Significant change in serum level of albumin was also observed, according to Ki Tae et al (2014) fall in serum level of albumin indicate liver damage and is also associated to oxididative stress related diseases.

In conclusion, Shea oil has significant effect on the histology of the liver tissue and may the toxic to liver as indicated by significant change in serum ALAT and albumin. It is therefore recommended that the consumption of Shea oil for medicinal or dietary purpose be done with moderation and further research carried out. 


\section{REFERENCES}

1. Boyd EM, Bereczky GM. 1965. Liver necrosis from paracetamol. Brit. J. Pharmacol. P. 606614.

2. Aguzue OC, Akanji FT, Tafida MA, Kamal J. 2013. Natural and some element composition of Shea (vittellaria paradoxa) fruit pulp. Archives of Applied science research. P 63-65.

3. Akinwale A, Modu S, Maisartu M, Zainab M. 2012. The effect of feeding various concentration of Shea oil on some biomedical parameters. BEPLS. P 14-15.

4. Phil. 2011. Anti-inflammatory effect of Shea oil. URL: http:// Www. HTNE.info.

5. Eyitayo L. 2007. Food and agricultural organization cooperate document.URL: http// Www. F. A. O. org.

6. Goldam L. 2003. Cecil text book of medicine. Philidephia W. B. Saunder.

7. Jamala GY, Jada MY, Joel J. 2003. Socioeconomic contribution of Shea tree (vitellaria Paradoxa) in support of rural livelihood in Ganye south-eastern Adamawa state Nigeria. JESTFT. P 75-81.

8. Nakate S. 2010. The Shea tree. URL: http:// www.buzzle.com [accessed December 2012.]

9. Tiniakos DG, VOS MB, Brunt EM. 2010. Non-alcoholic fatty liver disease pathology and pathogenesis. Annul Rev. P 145- 171.

10. Young B, James S, Stevens LA, Heath JW. 2006. The Histology of the Liver in weathers functional histology, a text and colour atlas, 5TH edn Churchill living stone. P 288-315. 11. 